\title{
Embattled Minority In-Between Minorities: An Analysis of British and German Salafi Anti-Jihadi Campaigns*
}

\author{
URIYA SHAVIT (University of Tel Aviv)
}

\begin{abstract}
Based on an analysis of 150 documents collected between 2012 and 2015 from bookstores, websites and YouTube channels operated by Salafi mosques and organisations in Britain and Germany, this article discusses the different strategies adopted in European Salafi discourse in an effort to disassociate salafiyya from al-Qaeda, ISIS and other Jihadi-Salafi movements. The article suggests that the target audience of these rebuttals are Western governments and publics, who suspect salafiyya to be a breeding-ground for terror, as well as mosque attendees, who are exposed to jihadi-salafi denunciations of Salafi anti-politics and anti-violence agendas. It introduces the diverse set of arguments invoked by Salafis to defend their opposition to violent attacks on Western soil, including the religious duties to abide by contracts, respect Islamic rules of warfare and the regulations on initiating jihad, avoid harming the interests of Muslims and of Islam in Europe, and oppose modern-day Khawarij of whom the Prophet Muḥammad warned.
\end{abstract}

Key words: Islam in Europe, salafiyya, jihadi-salafiyya, al-Qaeda, ISIS

\section{Introduction}

The term 'the Muslim minority in Europe', so commonplace today in popular and academic discourses, is reductionist and misleading. It postulates that for a majority of individuals of Muslim faith on the continent, the religious aspect of identity overrides all other aspects, including national, ethnic and socio-economic. This is not the case. It also postulates that the Muslims of Europe agree on a substantial enough body of religious doctrine and practice to render their analyses as a singular, coherent group instructive. This, too, is not the case. Rather than one 'Muslim minority', Europe is home to a variety of attitudes regarding the role of Islam in public and personal life, and to a variety of Muslim associations that fiercely debate core Islamic concepts and have demonstrated a greater tendency to split than to unite. True, with some exceptions, a majority of Muslims in Europe share the foundations of faith that all Muslims share. Also, a majority among Muslims in Europe shares a political interest in seeing their freedom of religion broadened, and their right not to be discriminated against protected. But in all other senses, there exists a plurality of minority Muslim groups.

One such group is the Salafis. Representing a tiny minority among Muslim populations in Europe, ${ }^{1}$ and an approach to Islamic law and theology that most European Mus-

* The author thanks Kfir Gross and Carl Yonker for their assistance. 
lims reject, the influence of their ideas is nevertheless greater due to their extensive influence in Islam-oriented bookstores and on the internet. The term salafi is used here in an empirical-descriptive way with no intention of passing judgment on the fraught issue of who is the 'real Salafi'. In contemporary Arabic, and particularly among Arabicspeaking Muslims in Europe, it defines groups that adhere to the teachings of Saudi Arabia's religious establishment and consider it a primary reference on theological and religio-juristic issues.

Since the 9/11 attacks, Salafis in Europe have faced a twofold challenge, exacerbated by subsequent attacks on European soil and, in recent years, by the voluntary migration of thousands of European Muslims to the ranks of ISIS. On the one hand, their authority has been undermined by Jihadi-Salafi groups who call for the application of violence as a political act against regimes in Muslim countries and in the West, and question the authority of scholars associated with the Saudi regime. On the other hand, they are challenged by European publics and policy makers (as well as by some rival Muslims) who do not recognise the difference between salafiyya and jihadi-salafiyya, or do, but suspect Salafi teachings to be a stepping stone to radicalisation. To sum up the gravity of the challenge, both the legal and religious legitimacies of European Salafis have been questioned, pressuring them to convince Western publics and policy makers that they do not support violence, and to convince their disciples that their rejection of violence is commensurate with the true meaning of Islam.

This article analyses strategies adopted by Salafi mosques and associations in Britain and Germany to disassociate from jihadi-salafiyya and assert the religious legitimacy of this disassociation. The first part is a brief introduction to Salafi doctrine, its particular views on Muslim minorities, and its differences with jihadi-salafiyya. The second part presents a comparative contextual discourse analysis of British and German Salafi texts that condemn jihadi-salafi organisations and, more specifically, violent attacks against Western societies. The analysis is based on a survey of British and German Salafi mosques' bookstores (including The Salafi Bookstore, Bradford; The Salafi Bookstore, Birmingham; and the bookstores of the Ibnu Taymeeyah Brixton Mosque; al-Nūr mosque, Berlin; al-Ṣahāba Mosque, Berlin; al-Raḥmān Mosque, Leipzig; and al-Muhsinīn Mosque, Bonn), as well as a survey of British and German websites and YouTube channels associated with Salafi mosques and organisations between 2012 and 2015, and interviews with imams and attendees of Salafi mosques. In total, some 150 publications and posts pertaining to the views of 'true' salafiyya on violence were analysed.

1 In June 2015, the Federal Office for the Protection of the Constitution (Bundesamt für Verfassungsschutz) put the number of Salafis in Germany at around 7,500, i.e., around 0.2 percent of the total Muslim population. Bundesamt für Verfassungsschutz (Federal Office for the Protection of the Constitution), accessed 5 February 2016: <https://www.verfassungsschutz.de/de/arbeitsfelder/af-islamismusund-islamistischer-terrorismus/was-ist-islamismus/salafistische-bestrebungen>. - Abū Huadīğa 'Abd al-Wahīd, one of three imams of the Salafi Mosque of Birmingham, the heartland of English salafiyya, estimated in an interview with the author (10 October 2015) that 4,000 of the city's 200,000 Muslims are Salafis. In other Salafi concentrations in England their share of the population is even smaller.

jحis • 17 (2017): 187-203 


\section{Salafiyya: An Introduction}

According to a tradition narrated by 'Abd Allāh b. 'Umar, the Prophet said: 'The best people are those living in my generation, and then those who will follow them, and then those who will follow the latter. Then there will come some people who will bear witness before taking oaths, and take oaths before bearing witness.' The tradition implies that the closer Muslims were to the days of the Prophet, the better their conduct was. It is the basis for a foundational point of consensus among Sunni jurists that the first three generations of Islam, known collectively as the pious ancestors (salaf), provide the example that Muslims should follow and, thus, are the ultimate reference for believers. Because of this consensus, different and contesting Islamic groups have sought to have their doctrines associated with the banner salafiyya. The great success of Saudi Arabia's Wahhabi religious establishment and its disciples abroad in doing so in recent decades owes much to the vast financial resources at the disposal of the world's leading oil producer. Contemporary Salafi works argue that their definition as 'Wahhabi', suggesting that they follow in the footsteps of an eighteenth-century scholar rather than those of the salaf, is an intentional insult on the part of those wishing to degrade them. ${ }^{2}$

Contemporary salafiyya considers itself heir to the legacies of Ahmad b. Hanbal (d. 241/855), Taqī al-Dīn Ibn Taymiyya (d. 728/1328), his student Ibn Qayyim al-Ğawziyya (d. 751/1350), and Muhammad b. 'Abd al-Wahhāb (d. 1206/1792), founder of the Wahhabi doctrine. Its two dominant contemporary voices are the Saudis 'Abd al-'Azīz b. 'Abd Allāh b. Bāz (d. 1999/1420), the Kingdom's highest ranking cleric since the early 1970s (and its grand muftī since 1993), and his second-in-command, Muḥammad b. Șaliḥ al- 'Utaymīn (d. 2001). Its highest authorities on jurisprudence are the Saudi Council of Senior Scholars (Mağlis Hay'at Kibār al-'Ulamä’), established in 1971, and its subsidiary, The Permanent Committee for Scholarly Research and Fatwas (al-Lağna al-Dä’ima li'l-Buhūt al-'Ilmiyya wa'l-Iftä). Most, but not all, prominent contemporary Salafis are Saudi-born.

Salafis consider themselves to be committed only to the teachings of the Quran and the Prophetic traditions and, thus, the emissaries of the beliefs and practices of the salaf. Central to their teachings are tawhìd (the oneness of Allah) as the guiding principle of Islam, and the rejection of širk (associating partners with Allah) ${ }^{3}$ and of bid'a (unlawful innovation). While these are core beliefs for all Muslims, Salafis apply them in a way that delegitimises opposing theological and religio-juristic views, as well as emphasises the importance of individual piety and the undesirability of political involvement. ${ }^{4}$ Salafis also

2 IBN JiBREEN 2007: 200-202. On the Saudi rejection of the term Wahhābiyya: ARMANIOS 2003: 1-3.

3 Ibn Bāz explained the centrality of tawhīd as follows: '[Islam's] reality is recognizing the oneness of Allah in His ownership, His control of affairs, and His actions. It is also singling Him out for worship and recognizing His uniqueness in His names and attributes. It is complying with His commands and accepting His law'. IBN BAAZ 2006: 12.

4 Șālih al-Fawzān, a member of the Saudi Council of Senior Scholars and of the Permanent Committee, answered his rhetorical question about why Salafis 'always talk about tawhìd' instead of discussing the plights of contemporary Muslims by insisting that in order to solve the problems Muslims face, it is essential 'to seek out the reasons that have led to the punishments afflicting the Muslims'. These reasons are the absence of tawhìd from the lives of most Muslims, manifested in behaviours such as praying to religious figures as intercessors with Allah, and clinging to graves and tombs, as well as not praying, 
emphasise that engagements with non-Muslims should be based on the principle of alwala $\vec{a}^{\prime}$ wa'l-bara $\bar{a}^{\prime}$ (loyalty and disavowal); the latter implies avoiding the imitation of nonMuslims, as well as refraining from extending friendship or loyalty to them. ${ }^{5}$ However, Salafis, including Ibn Bāz, have strictly prohibited violent attacks against non-Muslims and required that they be treated gently. ${ }^{6}$

The Salafi juristic approach is literalist, heavily drawing on the authority of the Prophetic traditions and restricting (while not rejecting altogether) the accommodation of religious laws to changing circumstances. Socially, Salafis preach for rigid gender segregation, require women to veil their faces for fear of fitna (temptation), strictly limit the roles of women in public spheres, and explicitly describe women as less intelligent than men. ${ }^{7}$ They also discourage leisure activities and prohibit playing and listening to music. ${ }^{8}$

Salafis maintain an elitist mentality. Drawing on a Prophetic tradition according to which the nation will divide into 73 sects, of which only one will escape hellfire, they believe themselves to be the 'saved sect'. ${ }^{9}$ First on their long list of rivals are Islamic political movements, especially those known in contemporary Arabic and in academic discourses as Jihadi-Salafi movements that blend the teachings of Sayyid Qutb (executed 1966/ 1386, the Muslim Brothers theorist who broke from the mainstream of the movement by suggesting

fasting, and giving charity as required. Only when tawhīd is established will Muslims be triumphant once more. Al-FAWZAAN 2007: 4.

5 Al-FAWZĀN 2013. Ibn Bāz explained that 'loyalty and disavowal' means loving the believers and being their friend (or ally), while despising the infidels, spurning them and their religion. IBN BĀZ, n.d.: 174; IBN BAZ 1996: 24-25. The Permanent Committee for Scholary Research and Fatwas argued that infidels, including Jews and Christians, are the enemies of Allah and His Prophet and are doomed to hellfire. AlLağna al-Dāima li'l-Buḥūt wa'l-Iftā' n.d.: 16-20. An introduction by an England-based president of a Salafi organisation to a treatise on al-wal $\vec{a}^{\prime}$ wa'l-bara $\bar{a}^{3}$, first published in 1997, explained that 'in the context of Islam, $a l$-wala $\vec{a}^{\prime}$ is loyalty to Allah and whatever He is pleased with as well as friendship and closeness to the believers, whereas al-bara ${ }^{3}$ is freeing oneself from that which is displeasing to Allāh and disowning the believers.' IBN MOHAR 1997: 4-5. For an overview of the development of this concept in Saudi Arabia: WAGEMAKERS 2012: 93-110; WAGEMAKERS 2008: 1-22; SHAVIT 2014: 67-88.

6 IBN BĀZ n.d.: 174-175.

7 To note one example, al-'Utaymīn considered apologetics about Islam as a religion of equality to be a lie. Islam, he argued, believes in justice, not equality, and justice is based on treating equally those who are equal and differentiating between those who are different. Women are different from men, who are stronger, tougher, and have a better capacity for understanding matters. Therefore, different laws are applied to them. For example, the testimony of one man is equivalent to the testimonies of two women because, while there are some women who are wiser than a man, 'such women are not in the majority' and Islamic law is based on what is most common. Women's 'reason is often overtaken by their emotions, and this happens to women more often than it happens to men'. Quoted by al-MUNAJJID 2007: 57-67.

8 Salafis draw from Ibn Taymiyya's depiction of music as strengthening satanic states. IBN TAYMIYYAH 2005: 341. They hold that decisions that legitimise music deviate from the ways of the salaf, and those who promote them have no knowledge of Islam. See al-Lağna al-Dā'ima li'l-Buhūt wa'l-Iftā' 2010: 277. The prohibition on music is strict. For example, Ibn Bāz ruled that it is only permissible to listen to radio programs that contain music if one turns down the volume when music is played. IBN BĀZ 1996: 324.

9 See the words of 'Abd al-Wahhāb and al-Fawzān's contemporary discussion on them: 'ABDUL WAHHAB 2010: 79-82. See also IBN BAZ 2008: 43-54; MĀLIK IBN ĀDAM n.d.: 4-5, 24-5, 57-60.

jحis • 17 (2017): 187-203 
in his book Milestones that any regime that does not apply Allah's laws exclusively is ğăhili and should be fought against), with Wahhabi social norms and a global outlook and global aspirations. ${ }^{10}$ Jihadi-Salafi groups include, most notably, al-Qaeda, a movement that sprang from Saudi Arabia and challenges the legitimacy of the House of Sa'ūd, and ISIS. Both pose a direct threat to the survival of the House of Sa ${ }^{c} \bar{u} d$. Thus, to effectively discredit their theological credibility is a primary political concern of the regime.

Since the 1970s, Salafis have produced a rich and distinct corpus of theoretical deliberations and fatwas on Muslim minorities. One foundation of their approach is that settlement in Western lands is undesirable, and can only be legitimised under specific circumstances and conditions. A primary justification is engagement in proselytising. Another foundation is that Muslim minorities are not entitled to any special concessions because of the unique hardships they encounter. This position is derived from the foundational Salafi view that Allah's laws are universal and should be interpreted and applied literally. Salafis hold that the duty to disavow applies also to majority non-Muslim societies, and thus encourage social isolation. These views differ from other conceptualisations on Muslims in the West, including those of the wasaț ('harmonising middle ground school') pragmatically-inclined Dublin-based European Council for Fatwa and Research, headed by the Qatarbased Egyptian jurist Yūsuf al-Qaraḍāwī. ${ }^{11}$

Since the 1990s, a Salafi presence has developed in European countries. Salafi organisations accept Salafi Saudi-based jurists and panels as a reference (marği iyya). They are led by imams who studied in Saudi Arabian universities or were inspired by graduates of these universities and endorse them. They publish and sell books, pamphlets, and sermons of Salafi scholars. With their thickly-bearded, traditionally-attired men and heavily veiled women, Salafi communities are easily recognisable, epitomising for some Europeans the 'non-integrated Muslim'.

There exist no pan-continental or even national-level Salafi panels or organisations that unite them. Rather, there are independently established mosques, associations, Islamic centres and publishers that function on a local level, often rivalling one another. Wiktorowicz's anatomy of the Salafi movement pointed to a split between the apolitical trend of 'purists' (who support the official line of the Saudi religious establishment, which opposes the involvement of religious scholars in politics - for obvious political motivations) and the 'politicos' who engage with politics as a means to generate socio-religious transformation. ${ }^{12}$ As demonstrated by Hamid, ${ }^{13}$ the conflict between the two trends contributed to divisions in English salafiyya in the 1990s, and, as observed by Wiedl, it also resonated in Germany. ${ }^{14}$ The absence of unity among European Salafis is not, however, always the

10 Hegghammer, who characterised Jihadi-Salafis as an extremist blending of the Wahhabi religious tradition and the Quṭbist Islamist trend and pointed to its internationalist orientation, traced the earliest origins of the term to an interview given in 1994 to the London-based jihadi magazine al-Anșa $r$ by Ayman al-Zawāhirī, al-Qaeda's current leader and a former member of the Egyptian Quṭist Islamic Jihad. HEGGHAMMER 2009: 251-255.

11 SHAVIT 2012.

12 WiKTOROWICZ 2006: 208.

13 HAMID 2008: 11.

14 WIEDL 2012: 14. 
result of core ideological debates. Salafi literalism and their sense of being a 'saved sect' and the only authentic representatives of Islam encourage the transformation of petty debates and personal dislikes into fierce rivalries. This reality has also been recognised and lamented by Salafi scholars. ${ }^{15}$ Notwithstanding these divisions, all Salafi organisations and leaders in Europe share an unequivocal resentment of Jihadi-Salafis.

Academic literature has extensively debated the extent to which the association of salafiyya with violent radicalisation, particularly among a minority of Muslim youths, is justified. A study published in 2007 by the New York Police Department (NYPD) analysed the backgrounds of terrorists involved in ten terror attacks in North America, Europe and Australia, and exposed a correlation between a period of engagement with Salafi literature and a later retreat from the radical environment and embrace of Jihadi arguments. ${ }^{16}$ A study in Germany suggested that while there are some 2,600 mosques in the country, 36.7 percent of the 110 German Muslim jihadists whose biographies were studied and whose attendance of a specific mosque could be verified had been attendees of six Salafi mosques. ${ }^{17}$ Rakic and Jurisic argued that through Saudi financing, Salafism incites fanaticism, intolerance and jihad, and urged European governments to address the challenge with greater firmness. ${ }^{18}$ Wiktorowicz argued that violent tendencies inherent to the ideology of Salafis render their communities a breeding ground for terrorists, but nevertheless cautioned against neglecting to differentiate between non-violent salafiyya and jihadi-salafiyya. ${ }^{19}$ Similarly, specifically addressing the German context, Logvinov noted the hate-speech of Salafis as a danger, but cautioned against not differentiating between Salafi variants. ${ }^{20}$ Abdel-Latif further challenged the correlation between salafiyya and violence. She argued that while jihadi-salafiyya receives disproportionate attention, the majority of Salafis (which she defined in very broad terms) are not radical. She advised Western governments to engage in dialogue with the Salafi mainstream, as do governments in the Arab world. ${ }^{21}$ In a similar vein, Lambert noted that many Salafis are at the forefront of the fight against terror and argued that their labelling as jihadi by security organisations is counterproductive. $^{22}$

15 See for example in Ar-RAYYIS 2010. His words of preaching lamented that 'many of the Salafi centers in Europe - after being places of knowledge, learning and study — change into places of differing, problems and argumentation among the Salafi themselves'. Al-Rayyis called European Salafis to change course and to realise that there are issues on which there can be differences of opinion, as well to appreciate that not every person with ties to Saudi Arabia is necessarily correct in what he says.

16 SILVER \& BHATT 2007: 16-85.

17 HEERLEIN 2014: 169

18 RAKIC \& JURISIC 2012: 650-663.

19 WiKTOROWICZ 2001: 18-38.

20 Loginov 2012.

21 ABDEL-LATIF 2009: 69-86.

22 LAMBERT 2008: 31-35.

jحi • 17 (2017): 187-203 


\section{British and German Salafi anti-Jihadist Discourses}

In interviews by the author with Salafi leaders in Germany and England, they stressed their commitment to swaying youth away from the path of violence, and the positive impact their activities have. At al-Muhsinīn Mosque, Bonn, I was told that whenever a young attendee is getting the wrong ideas from the internet, he or she is taken to the imam, who explains them what true Islam is about. Muslims living in the West signed a contract with their state, and Muslims must abide by contracts. Thus violence is not an option for the true Muslim. ${ }^{23}$ Nūr al-Dīn Abū 'Abd Allāh, the imam of Daar us-Sunnah mosque in Shepherds Bush, London, said he resented the association of the terms jihadi and salafi. He noted that he was active in propagating in schools against al-Qaeda and the Islamic State, and that he believed Salafi preaching is the only cure against violent radicalisation, because it presents Muslims with true Islam. ${ }^{24}$

These views are systematically developed in Salafi texts. A survey of bookstores attached to Salafi mosques in Britain and Germany, as well as of internet websites and YouTube channels associated with Salafi organisations in both countries, revealed rich and anxious discourses aimed at affirming the distinction between Salafis and Jihadi-Salafis and convincing individual Muslims that joining the ranks of violent groups constitutes deviation from Islam. While both discourses are unequivocal in their utter opposition to violent attacks, the anti-Jihadi-Salafi discourse in Britain is far more prolific and organised than the German one, and presents a more diverse and religio-juristically developed body of arguments. It involves a plethora of books, articles, leaflets and audio and visual posts that are dedicated exclusively to this issue, whereas in Germany it is based largely on occasional sermons recorded and posted on YouTube.

The reason for this discrepancy is not that German Salafis are less motivated to condemn violence against Western targets. On the contrary, because salafiyya is defined by Germany's Federal Ministry of the Interior and the agency for the protection of the constitution (Verfassungsschutz) as a movement that challenges German democracy, and mosques labelled as Salafi are subsequently placed under surveillance, German Salafis are motivated to unequivocally condemn violence, and at times do so outlandishly. (One example is two posters hung on the windows of the Salafi al-Raḥmān mosque in Leipzig for all passers-by to see: 'Wir sind gegen Terror, Gewalt; Wir sind für Frieden, Dialog, Integration' - 'We are against terror, violence; we support peace, dialogue, integration'). ${ }^{25}$

Two other explanations come to mind. First, whereas the English roots of salafiyya are traced to the early $1990 \mathrm{~s},{ }^{26}$ those of German salafiyya are traced to the early $2000 \mathrm{~s}^{27}$ Salafis in Britain have more resources, and have, in general, independently published a far greater body of works than German Salafis have. Second, expressions of globalist

23 Interview with one of the mosque leaders, who asked not to be identified, Bonn, 27 July 2013.

24 Interview with the author, London, 7 October 2015.

25 As documented by the author on 29 July 2013.

26 HAMID 2008: 10-11.

27 WIEDL 2012: 17. 
political Islam, including those of the Muslim Brothers and Hizb al-Tahrīr, who Saudi Salafis particularly seek to refute, are far less prominent among Muslims in Germany than they are in Britain. Thus, the German Salafi discourse is in general less preoccupied with the Salafi concept of individual piety and abstention from political meddling than the British.

There is an element of apologetics, directed towards non-Muslim majorities-especially their governments and law enforcement authorities-in both British and German Salafi preaching against violent activities. Salafi texts seek to separate their approach in the public mind from jihadi-salafiyya and, moreover, to establish their doctrine as the most effective means of combating radical tendencies, and, thus, an esteemed ally in the battle against radicalism. One example is a Salafi treatise that argued that to associate Salafi theologians with al-Qaeda is similar to arguing that Fidel Castro is an ardent supporter of democracy. Salafiyya and terror, it stated, are like oil and water. ${ }^{28}$ Another treatise bemoaned the large amounts of money that are wasted by Britain on organisations and think tanks that promise to lead counter-radicalisation efforts but cannot deliver because of their paltry status among Muslim communities. It suggested that the only way to effectively appeal to the minds of those who support jihadi operations is to provide them with evidence based on the Quran and the Prophetic traditions and counter their claim for being the authentic representation of Islam with a more convincing one. ${ }^{29}$

Still, the primary target audience of Salafi anti-violence campaigns in Britain and Germany is Muslims living in the West, first and foremost the young and easily impressed, who are also the ones most likely to be exposed to Salafi sources. In making the case against al-Qaeda, ISIS and other Jihadi-Salafi organisations, Salafi preachers introduced an array of arguments that describes acts such as the 7/7 attacks on the London underground and Charlie Hebdo attacks as a breach of different Islamic norms, as acts that damaged the welfare of Muslims at large and the prospects of spreading Islam in the West, and a continuation of a historical legacy of deviation against which the Prophet Muhammad warned. The unifying theme is authenticity: Salafis_adhering to a doctrine whose raison d'être and central source of appeal is its claim to adhere loyally to the teachings of the Prophet and his Companions-struggle to demonstrate that their rejection of violence is the correct interpretation of Islam, whereas violent attacks by Muslim residents of Western countries represent a deviation that must be rejected not for fear of Western security apparatuses, but for fear of Allah. The following are the main arguments presented in this discourse.

\section{Abiding by contracts}

This argument emphasises the duty of Muslims living in the West to abide by the Islamic norm of respecting contracts. Visas given by Western countries, and citizenship in Western countries, are regarded as a breached contract if one actively joins the ranks of an enemy while still under the contract. The implication is that regardless of how one feels about the West, and regardless of whether one believes that violent attacks are beneficial to Muslim

28 Al-AKHDAR 2002: 10-11

29 MAHDI 2010: 9-13.

jحis • 17 (2017): 187-203 
causes, there are certain obligations all Muslims must abide by that render attacks, such as the 9/11, 7/7, Charlie Hebdo or Paris Attacks, prohibited acts. Thus, Muslims who refrain from joining the ranks of al-Qaeda, ISIS or independent groups exercise self-control and true devotion, not allowing emotions, even when running high, to overcome their duties to Allah.

The contractual argument is also invoked by rivals of salafiyya. For example, Ahmad Ğāballāh, a member of the European Council for Fatwa and Research, argued that even in cases when a non-Muslim country acts unjustly against others, including Muslims, Muslims in that country cannot betray their government because Islam prohibits the breaching of contracts. ${ }^{30}$ However, whereas in the wasaț case this argument is invoked as part of a broader legitimisation of extending loyalty and friendship to non-Muslims (and as such, a refutation of the Salafi concept of 'loyalty and disavowal'), Salafis invoke it narrowly as a means of making the point that while 'disavowing' is part of the faith, it should by no means involve using violence.

One example is 'Words to the Muslim youth of Britain' by al-'Utaymīn, published at least twice in the newsletter of a Bradford-based Salafi organisation as part of its anti-jihadi campaigns. Relying on a tradition according to which the Prophet said that whoever kills someone who is under an agreement will not smell the fragrance of paradise, al-'Utaymīn stated that Muslims should respect the majority non-Muslim societies in which they reside, because

The land in which you are living is such that there is an agreement between you and them. If this were not the case, they would have killed you or expelled you. So preserve this agreement, and do not prove treacherous to it, since treachery is a sign of the hypocrites, and it is not from the believers. ${ }^{31}$

The Salafi author 'Abd al-Raḥmān Mahdī presented the contractual argument as a response to what he defined as the 'emotional arguments' invoked by Muslims in the West who commit violent acts. Emotional arguments include that the kuffār (infidels) have betrayed Muslims and, therefore, it is allowed to betray them; that British and American soldiers kill Muslims in Iraq and in Afghanistan, so it is allowed to kill them in their countries; and that the kuffār have acted treacherously towards the Muslims in Palestine and Somalia through their support of Israeli and Ethiopian aggressions respectively, so their blood is lawful to Muslims. According to Mahdī, none of the abovementioned grievances justify acts of violence. Unlike the emotional, misguided Muslim, the informed Muslim will recognise that respecting a covenant, i.e., visa or citizenship, to which he is a party, is a fard 'ayn-an

30 ĞĀBALLĀH 2008: 264.

31 Al-'UTAYMĪN 2007: 2; al-'UțAYMīn n.d.: 2. Compare with the words of a disciple of Ibn Bāz and al'Utaymīn, Șāliḥ al-Munağğid (or al-Munajjid, as he uses in the English version of his website) who operates the Arabic and English 'Question and Answer' website. According to al-Munajjid, Muslims residing in non-Muslim societies must remember that it is 'obligatory upon a Muslim to honor treaties or agreements made with a non-Muslim party. If a Muslim has agreed to their conditions when seeking permission to enter their country (i.e., a visa) and has promised to adhere to that, then it is not permissible for him to commit mischief in their lands, to betray anyone, to steal, to kill or do any destructive actions and so on.' Al-MUNAJJID 2003: 70-71. 
individual duty (similar to the duty to pray or fast, and unlike a communal duty, fard kifāya, from which one is exempted if it is performed by the community in a satisfactory manner). Thus, 'individual Muslims in non-Muslim states are required to fulfill their obligations as citizens or visitors, vis-à-vis their particular relationship with their non-Muslim authority, regardless of what occurs between it [the Western authority] and other parties of Muslims'.

\section{Regulating jihad}

According to Salafi anti-jihadi preaching, Muslims in the West who join the ranks of alQaeda, ISIS and affiliated groups are also in breach of the Islamic norms that regulate the initiation of and participation in jihad. Like the contractual argument, this argument avoids the more sensitive question of whether acts by Western Muslims against Western targets are desirable by suggesting that they are religiously illegitimate regardless of their impact. Emphasising that 'ISIS are not Salafi', the 'Salafi English' group posted on YouTube the words of Rabī' b. Hādī al-Madhalī a former head of the Department of Sunna at the Islamic University of Medina, and a vocal opponent of political involvement by religious scholars. He stated that while Allah honoured the Muslim nation with jihad, jihad has guidelines, conditions and principles; it must be declared by the leaders of the nation, and not by individuals who create nothing but mayhem and disorder, calamity and corruption. ${ }^{33}$

Similarly, a leaflet published by the Birmingham-based Salafi Bookstore on the ways to combat ISIS and al-Qaeda noted that Muslims may participate in jihad only if war is declared by leaders and governments and not by 'individual citizens, or insurgents and pulpits, or through social media!' Hinting at the discrepancy between al-Qaeda's and ISIS's global ambitions and their limited military capabilities, the leaflet further established that a legitimate Muslim army that engages in jihad must have the necessary strength to fight or repel attacks and, if not, it is permitted to retreat or initiate peace treaties. ${ }^{34}$

\section{Just warfare}

Salafi anti-jihadi preaching states that Muslims must, at all times, respect the Islamic regulations on the conduct of warfare. This argument, too, suggests that regardless of their motivations and effects, the operational methods applied by al-Qaeda, ISIS and individuals who identify with them, whether in the Middle East or on European soil, are illegitimate because they breach clear instructions given by the Prophet that are valid at all times and in all circumstances.

For example, Hasan Dabbāg, the imam of the Leipzig al-Rahmān mosque, explained in a sermon posted on YouTube that Islam is a religion that rejects extremism and terrorism and forbids killing innocent people and 'committing bad acts'. He emphasised that he was making this point not because he was concerned about how Germans view Islam, but because this was what Muslim faith requires. ${ }^{35}$ Abdul Adhim Kamouss, a charismatic

\footnotetext{
32 MAHDI 2010: 48-49.

33 al-MADKHALI 2014.

34 Combating $21^{s t}$ Century Violent Extremist Terrorism n.d.

35 DABBAGH 2008.
}

jحis • 17 (2017): 187-203 
Berlin-based Moroccan preacher and the subject of much media controversy in Germany over his alleged radicalism, described in great detail, seething with disgust and astonishment, beheadings and mass executions by ISIS, judging them to be repulsive atrocities that counter the spirit of Islam. He defined ISIS as a virus and a poisonous seed. ${ }^{36}$ In another sermon he emphasised the importance of treating non-Muslims with respect and the sanctity of all human lives. ${ }^{37}$ The above-mentioned leaflet by the Birmingham-based Salafi Bookstore stressed that Muslims who engage in jihad must not harm noncombatants, including 'women, children, monks, emissaries, teachers, nurses, doctors, aid workers and others', ${ }^{38}$ whereas the aforementioned treatise by Mahdī emphasised that 'Islam unequivocally forbids the targeting of non-combatants during times of war or peace. An act of violence, suicidal or otherwise, against innocent or otherwise peaceful men, women and children is, simply, terrorism'. As part of his defence for his opinion, Mahdi cited the instance in which the Prophet once passed an idolatress who had fallen during a battle. He denounced her killing, insisting that the woman was not the one against who war was to be fought. ${ }^{39}$

\section{The mașlaha of Islam and Muslims}

Another argument against jihadi-salafi acts is that they lead to the characterisation of Muslim citizens as a potential fifth column and raise alarm about Muslim organisations at large, and thus injure the public interest of Muslim communities and damage the ability to propagate Islam. In this context, violent attacks are presented as a mafsada (an action that is the opposite of mașlaha in that it harms the fulfilment of one of the primary objectives of the sharia).

For example, in a 'warning against the extremists', published by a Bradford-based Salafi organisation in response to the $7 / 7$ attacks, 'Abd al-Mụsin al-'Ubaykān (a member of the Council of Senior Scholars and the Permanent Committee), argued that the attacks resulted in 'many negatives': they damaged coexistence between the British people and the Muslim minority in Britain, and have placed the latter in 'a difficult position and, perhaps, caused some aggravation. The least of them being that this has portrayed Muslims as a possible security threat.' Acts such as 7/7, argued al-'Ubaykān, damage the reputation that the Muslim minority in Britain has gained and the rights it has acquired, and those plotting acts of violence should be exposed and uprooted so as to allow the Muslim population to live in peace and spread true Islam. ${ }^{40}$ In a similar vein, the leaflet published by the Salafi Bookstore in Birmingham on combating al-Qaeda and ISIS emphasised, based on verses $60: 8-9,{ }^{41}$ that the Quran demands that Muslims deal justly and kindly with non-Muslims

KAMOUSS 2014.

Ibid.

Combating 21st Century Violent Extremist Terrorism n.d.

39 MAHDI 2010: 35.

40 Al-UBAYKAAN 2007: 3.

41 The verses state: 'Allah does not forbid you from those who do not fight you because of religion and do not expel you from your homes-from being righteous toward them and acting justly toward them. Indeed, Allah loves those who act justly. Allah only forbids you from those who fight you because of religion and expel you from your homes and aid in your expulsion - forbids that you make allies of them. And whoever makes allies of them, then it is those who are the wrongdoers.' The Quran 1997. 
who do not fight against them, and cautioned that modern-day 'extremist-Islamists' marred the beauty of Islam and turned 'countless people away from looking into the true message of the Prophet Muhammad'. Based on this evaluation, the leaflet called on Muslims who learn about individuals who incite or plan 'terrorist acts such as suicide bombings, kidnapping or killing' to inform the authorities, regardless of whether said acts are to be perpetrated in Muslim or non-Muslim countries. ${ }^{42}$

\section{Historical analogy}

In 656/35, the third caliph, 'Utimān, was assassinated, and the Prophet's cousin, 'Alī, took his place. The power struggle that ensued between $\mathrm{Mu}^{`}$ āwiya, the governor of Syria and a relative of 'Uțān, and 'Alī's supporters, reached a climax in Șiffīn in 657/37, when Mu'āwiya's supporters lifted spears with pages of the Quran and called for the dispute to be settled by a group of arbitrators. 'Alī reluctantly accepted this proposition. Some of his supporters believed that he made a grave mistake, arguing that the Quran commands that they continue fighting. As a result, they split from his camp and came to be known as the Khawarij ('those who left', or 'the renegades'). They developed a political theology according to which only an individual recognised by consensus as the best of Muslims is a legitimate caliph, and continuously rebelled against the House of the Umayyads. Their political legacy challenges a broad agreement that developed in Sunni jurisprudence (and is especially highlighted by Salafis) that places harsh restrictions against launching armed rebellions against Muslim leaders, even sinning and failing ones. ${ }^{43}$

Salafi British and German preaching against Jihadi-Salafism draws a direct link between the Khawarij, the teachings of Sayyid Quṭb, Egyptian Jihadi groups that applied Quțb's doctrine, and contemporary groups such as al-Qaeda and ISIS, which do not recognise any of the existing Muslim regimes as legitimate. The Khawarij, who were ultimately on the losing side of Islamic history, came to be broadly regarded as a deviant group, beyond the pale of legitimacy. The analogy between them and the modern enemies of salafiyya is intended to delegitimise them.

Examples vary, demonstrating the centrality of this analogy in the Salafi anti-jihadi discourse. A Berlin-based Salafi preacher, Ahmad Abū 'l-Barâ', drew a parallel between the Khawarij, whom the Prophet said would kill Muslims but spare the lives of idolworshippers, and ISIS, who, according to al-Barā', do exactly that. He called on Muslims to heed the Prophet's warning against those who seem to follow the Quran and appear devout

42 Combating 21 st Century Violent Extremist Terrorism n.d.

43 Perhaps the best known articulation of this position was Abū Hāamid al-Ġazālī’s (d. 505/1111). He held that without a ruler, order and stability are impossible, and thus a corrupt ruler, who came to power unlawfully, is preferable to anarchy. GIBB 2001: 10-11. Another prominent example is Ibn Taymiyya (d. 728/1328), who believed that to rule a people is one of the most important religious duties, without which religion cannot exist. He held that the ruler, responsible for maintaining law and order and enabling the believers to perform their duties towards Allah, was to be entrusted with absolute powers, regardless of his character, the title he assumes, or how he came to power. Four centuries before Thomas Hobbes, he suggested that people's willingness to obey kings, regardless of whether they are religious or not, is a result of their understanding that it is the only way to secure their well-being. IBN TAYMIYYA n.d.: 161; al-ENAZY 2010: 13-15; RAWĀS 1998, vol. 1: 285-300. 
but, in fact, are not. ${ }^{44}$ In his 'warning against the extremists', al-'Ubaykān relied on this analogy to argue that those responsible for violent attacks are actually worse than the original Khawarij because they had added to the sin of unjustified excommunication by 'violating their covenants and transgressing against the people of the book and other than them, who have agreements with the Muslims'. ${ }^{45}$

In January 2015, following the attacks on the staff of Charlie Hebdo in Paris, an English Salafi website dedicated to fighting extremism published the reaction of the Medina-based da'wa activist, 'Ubayd al-Ğābirī, who described the assassinations as acts of Khawarij, 'the scum, the savages and the anarchists'. Echoing the Salafi portrayal of the Muslim Brothers (Ihwānī) as a group that leads Muslims astray, al-Ğābirī suggested that the attacks had been orchestrated by Ihwānī activists who wished to injure the position of Salafis living in the West by provoking the resentment of the majority society. He advised Muslims residing in the West, specifically their imams, to 'openly announce [their] disavowal and innocence from this action and other actions of anarchy'. Invoking the aforementioned contractual argument, he emphasised that 'the people of the Sunna' living in Europe and America recognise that there is an agreement, a covenant, between them and their receiving lands that they must never violate. ${ }^{46}$ A book disseminated by the same website detailed the history of the Khawarij and the Prophetic traditions anticipating and condemning them, and described al-Qaeda and ISIS as their modern reincarnation, noting that 'they do not serve the interests of Muslims, their governments, nations or lands' ${ }^{47}$ Mahdī stressed that just as the Khawarij were not considered a legitimate expression of pluralism in Islam, so alQaeda cannot be considered to be one. Emphasising that the Khawarij were 'derided for their deviation and self-amputation from the orthodox Muslim body', the author argued that it is just as right to oppose their 'modern-day incarnation'. ${ }^{48}$ A leaflet distributed by the London Masjid Daar us Sunnah invoked several Prophetic traditions that warned against the future rise of the likes of the Khawarij, noting that the Prophet predicted that the Khawarij will be 'young of age' and 'foolish of mind' as indeed are those who join the imposter caliph, Abū Bakr al-Baġdādī, and his Islamic State. ${ }^{49}$

\section{Conclusion}

An array of arguments has been invoked by Salafis in Britain and in Germany as part of their efforts to refute the accusations that they cultivate radicalisation and to assert the religious legitimacy of their rejection of violence. These include the religious duties to abide by contracts; respect the Islamic rules of warfare and jihad; avoid harming the inter-

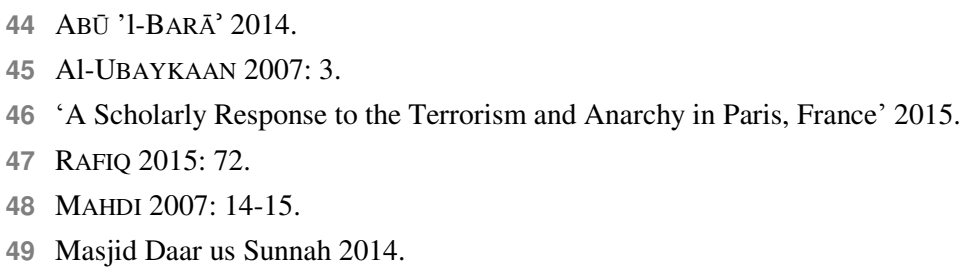


ests of Muslims and of Islam in Europe; and oppose modern-day Khawarij against whom the Prophet Muhammad warned.

Salafi anti-violence preaching has been directed at two audiences: Western governments and publics, whom Salafis aim to convince that salafiyya is not a security risk; and Muslims, whom they aim to convince that violence is not the way of the salaf. These teachings in no way constitute a break from the generally anti-liberal, pro-separateness Salafi agenda. What Salafis argue is that while Muslims in Europe should disavow nonMuslims, oppose liberal norms and reject integration, they must, at the same time, refrain from joining, or supporting, jihadi attacks against Western targets in any way.

Data as to the actual effect of anti-jihadi preaching are inconclusive and call for further research. Arguments for the positive influence exposure to Salafi doctrine has on some Muslims conflict with evidence for the relatively high levels of involvement of former attendees of Salafi communities in terror activities. A possible explanation is that Salafi views have a different effect on people in different situations. Salafi leaders are confident that their mosques are the most reliable firewall against violent radicalisation. But calls for restraint, voiced as part of a broader doctrine of intolerance, risk falling at times on deaf ears.

\section{Bibliography}

\section{Sources}

'A Scholarly Response to the Terrorism and Anarchy in Paris, France', 9 January 2015, <http://www. islamagainstextremism.com/articles/rktebvz-a-scholarly-response-to-the-terrorism-and-anarchyin-paris-france.cfm> (accessed 15 September 2015).

Abdul-Rahman, Muhammad Saed (ed.). 2003. Islam: Questions and Answers-Alliance and Amity, Disavowal and Enmity. London: MSA Publication Ltd.

— . 2007a. Islam: Questions and Answers_Inviting Others to Islam. London: MSA Publication Ltd.

-. 2007b. Islam: Questions and Answers-Basis for Jurisprudence and Islamic Rulings. London: MSA Publication Ltd.

'ABdul Waннав, Muhammad Ibn. The Best Religion for Mankind / explained by Saalih Ibn Fawzaan Ibn 'Abdullah al-Fawzaan. New York: Daarul Isnaad, 2010.

ABŪ 'L-BARĀ', Aḥmad. 2014. "Wer sind die ISIS? Sollte ein Muslim sie unterstützen?”, 21 August 2014: <https://www.youtube.com/watch?v=iKfeZZy621s\&feature=youtu.be> (accessed 15 September 2015).

al-AKHDAR, Abul al-Hasan Maalik. 2002. In Defense of Islam in Light of the Events of September $11^{\text {th }}$. Toronto: T.R.O.I.D Publications.

Combating $21^{\text {st }}$ Century Violent Extremist Terrorism: ISIS, al-Qaeda in Iraq \& Syria-A Must Read: The Islamic Salafi Position towards Extremist insurgencies in light of Quranic and Prophetic Teachings. Salafi Publications. Birmingham: The Salafi Bookstore, n.d.

DabbaGH. Hassan. 2008. "Unsere Haltung zum Extremismus”. FlaggeDerSunna: <https://www. youtube.com/watch?v=xAIJEvU8NrY> (accessed 15 September 2015).

Fatāwā al-Balad al-Harām. Al-Qāhira: Dār al-Tawfīqiyya, n.d.

al-FAwZAAn, Saleh. 2007. "Why Do the 'Wahhabis' Always Talk About Tawheed?” The Ark, 21: 4.

jحis • 17 (2017): 187-203 
al-FAWZĀN, 'Abd Allāh b. Șāliḥ. Aḥkām al-Tašābuh bi’l-Kuffār, n.d.: <alfuzan.islamlight.net/ index.php?option $=$ com_remository \&id $=\&$ Itemid $=0 \&$ limit $=50 \&$ limitstart $=0>($ accessed 10 November 2013).

al-FouZAn, Saalih bin Fouzan. 1997. Al-walaa' wal-baraa': Allegiance and Association With the People of Islaam and Eeman and Disassociation and Enmity with the People of Falsehood and Disbelief in Islaam / trans. Abu Abdur-Rahman Bansfield. Ipswich: Jam'iat Ihyaa' Minhaaj AlSunna.

ĞĀBALLĀH, Aḥmad. 2008. "Al-Wasațiyya bayna Muqtaḍayāt al-Muwāṭana fī Ūrūbā wa'l-Hifāẓ 'alā al-Huwiyya al-Islāmiyya”. Al-Mağalla al-Ilmiyya li'l-Mağlis al-Ūrūbì li'l-Ifta’’ wa'l-Buhūt, 12-13.

IBN BAAZ, Al-Imaam 'Abdul 'Azeez Ibn 'Abdullah. 2006. The Legislation of Islam / trans. Abū Sumayya 'Aqīl Walker. Grand Prairie: Ibnul Qayyim Publications.

IBn BĀZ, 'Abd al-'Azīz b. 'Abd Allāh. 1996. "Ruling Concerning Listening to Radio Programs That Contain Music”. In: al-MusnAD (ed.). 1996: 324.

- . "Al-walā' wa'l-barā̄' wa-aḥkām al-kuffār”. In: Fatāwā al-Balad al-Harām n.d.: 174

IBN BAZ, Abd el-Aziz bin Abdullah. 1996. The Correct Belief and Its Opposite and what Negates AlIslam / trans. Muhammad 'Abd al-Raḥman Abū Ḥamza Maghribī. London: al-Firdous.

— . 2008. The Correct Islamic Aqīdah. Birmingham: Daar us-Sunnah Publishers.

IBN JibreEN, 'Abd Allāh. 2007. "Advice to Those Who Do Not Recognize the Salafi Scholars and Call Them Wahhabis”. In: ABDUL-RAHMAN (ed.). 2007a: 200-202.

IBN MoHAR, 'Alī Abū Muntașir. "Introduction”. In: al-FouZAn 1997: 4-5.

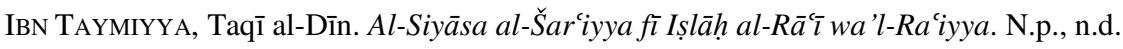

IBn TAYмiYyah (Shaykhul-Islam). The Friends of Allah \& The Friends of Shaytan / trans. Abu Rumaysah. Birmingham: Dar us-Sunnah Publishers, 2005.

Kamouss, Abdul Adhim. 2014. "Wer sind die ISIS?", 28 September 2014: <https://www.youtube. $\mathrm{com} /$ watch? $=\mathrm{qOAJHcNEqOk}>$ (accessed 15 September 2015).

— . 2014. "Das Verhalten gegenüber Nichtmuslimen", 17 September 2014: <https://www.youtube. com/watch? $\mathrm{v}=-\mathrm{GQF} 1 \mathrm{XL} 35 \mathrm{j} 8>$ (accessed 15September 2015).

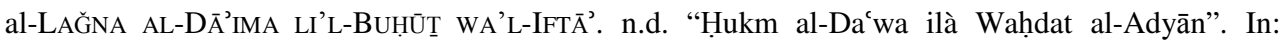
Fatāwā al-Balad al-Harām: 16-20.

— . "Al-Ištigāāl bi'l-Mūsīqā wa'l-'Ilāğ bihā". In: al-ŠAF̄̄ì (ed.) 2010: 277.

al-MadKhali, Muhammad b. Hādī [sic!]. "ISIS is a Terrorist Organization”. Salafi English, 28 August 2014: <https://www.youtube.com/watch?v=fhZdKotfqto\&index=5\&list=PLiSA7IQ_ W8GCHbuSnVJ5YaFQPiRDkZGR> (15 accessed September 2015).

MAHDI, AbdurRahman. 2010. Martyrdom in Jihad versus Suicide Bombing. London: Islamic Knowledge.

MĀLIK IBN ĀDAM, Abū al-Hasan (ed.). N.d. The Crime of Hizbiyyah against the Salafi Da'wah. Grand Rapids, MI: Sunna Publishing.

MASIID DAAR US SUNNAH. 2014. A Warning against Terror Groups ISIS \& al-Qaedah and the Correct Islamic Position Regarding Them. (Unnumbered document), 20 August 2014.

al-MunaJJID, Muhammad Salih. 2003. "Principles and Guidelines for Muslims' relations with nonMuslims". In: ABDUL-RAHMAN (ed.) 2003: 70-71.

—. "Does Islam Regard Men and Women as Equal?" In: AbDUl-RAHMAN (ed.) 2007: 57-67.

al-MuSnAD, Muhammad bin Abdul-Aziz (ed.). 1996. Islamic Fatawa Regarding Women. Riyadh: Darussalam Publishers and Distributers. 
The Quran. 1997. Sahīḥ International edition: Riyāḍ.

RAWĀs, Muḥammad. 1998. Mawsū'at Fiqh Ibn Taymiyya. Bayrūt: Dār al-Nafā’is, vol. 1.

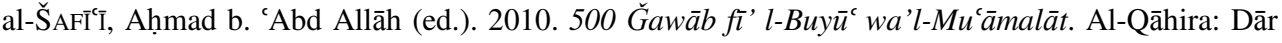
Ibn Hazm.

al-UbaykaAn, Abdul Muhsin. 2007. "7/7 A Warning against the Extremists". The Ark, Special Edition, 21: 3 .

al-'UțAymīn, Muḥammad b. Șāliḥ. 2007. "Wahhabis' Call for the Bad Treatment of non-Muslims". The Ark, Special Edition, 21: 2.

\section{Secondary Literature}

Abdel-Latif, Omaya. 2009. "Trends in Salafism”. In: Emerson / Kausch \& Youngs (eds.). 2009: 69-86.

Aвou El FadL, Khaled. 2001. Rebellion and Violence in Islamic Law. Cambridge: Cambridge University Press.

ARmAnios, Febe. 2003. The Islamic Traditions of Wahhabism and Salafiyya, Congressional Research Service Reports.

BundeSAMT FÜR VeRfassungsSChUtZ (Federal Office for the Protection of the Constitution): $<$ https://www.verfassungsschutz.de/de/arbeitsfelder/af-islamismus-und-islamistischer-terrorismus/ was-ist-islamismus/salafistische-bestrebungen $>$ (accessed 5 February 2016).

EMERSON, Michael / KAUSCH, Kristina / Youngs, Richard (eds.). 2009. Islamist Radicalisation: The Challenge for Euro-Mediterranean Relations. Brussels and Madrid: Centre for European Policy Studies and Fride.

al-EnAZY, Askar H. 2010. The Creation of Saudi Arabia. London and New York: Routledge.

GiBB, Hamilton. 1955. “Constitutional Organization”. In: KHADDURI \& LiEBESNy (eds.). 1955: 3-27.

HAMID, Sadek. 2008. "The Development of British Salafism”. ISIM Review, 21.1: 11.

HeERLEIN, Alexander. 2014. "'Salafistische' Moscheen-Ort des Gebets oder eine Brutstätte für Dschihadistische Muslime?’. In: LoginOv \& HuMmel (eds.) 2014: 155-181.

HegGhammer, Thomas. 2009. "Jihadi-Salafis or Revolutionaries? On Religion and Politics in the Study of Militant Islamism”. In: MEIJER (ed.) 2009: 251-255.

KhadDuRI, Majid / Liebesny, Herbert J. (eds.). 1955. Law in the Middle East. Washington D.C: The Middle East Institute.

LAMBERT, Robert. 2008. "Empowering Salafis and Islamists against Al-Qaeda: A London Counterterrorism Case Study". Political Science \& Politics, 41.1: 31-35.

Loginov, Michail. 2012. Salafismus in Deutschland: Zwei Gefahrendimensionen (Analysis for the Union of the German Criminal Investigative Police): <http://www.kriminalpolizei.de/ ausgaben/2012/juni/detailansicht-juni/artikel/salafismus-in-deutschland-zwei-gefahrendimensionen. html > (accessed 22 September 2015).

— / Hummel, Klaus (eds.). 2014. Gefährliche Nähe: Salafismus und Dschihadismus in Deutschland. Stuttgart: Ibidem.

MeIJer, Roel (ed.). 2009. Global Salafism: Islam's New Religious Movement. London: Hurst \& Company.

RAFIQ, Abu Iyaad Amjad bin Muhammad. 2015. The Kharijites: Historical Roots of the Ideology of the Muslim Brotherhood, Hizb al-Tahrīr, al-Qā'idah, al-Nușrah and ISIS. Birmingham: Salafi Publications.

jحis • 17 (2017): 187-203 
RAKIC, Marko / JuRISIC, Dragisa. 2012. "Wahhabism as a Militant Form of Islam on Europe's Doorstep". Studies in Conflict \& Terrorism, 35.9: 650-663.

ar-RAYYIS, Abdul-Aziz. 2010. The Beautiful Advise to The Noble Salafis of the West / trans. 'Abd alHaqq Al-Ashanti. London: Jamiah Media.

Shavit, Uriya. 2012. "The Wasațī and Salafī Approaches to the Religious Law of Muslim Minorities". Islamic Law and Society, 20.4: 416-457.

— . 2014. "Can Muslims Befriend Non-Muslims? Debating al-Walä' wal-Barā̄ in Theory and Practice". Islam and Christian-Muslim Relations, 25.1: 67-88.

Silver, Mitchell D. / BhatT, Arvin. 2007. Radicalization in the West: The Homegrown Threat. New York: New York Police Department, Intelligence Unity.

— . n.d. "How Muslims Should Behave in non-Muslim Societies". The Ark, 33: 2.

WAGemakers, Joas. 2008. "Framing the 'Threat to Islam': al-walā’ wal-barā’ in Salafi Discourse". Arab Studies Quarterly, 30.4: 1-22.

- . 2012. "The Enduring Legacy of the Second Saudi State: Quietist and Radical Wahhabi Contestations of al-Wala' wal-Bara"'. International Journal of Middle Eastern Studies, 44.1: 93-110

WIEDL, Nina. 2012. The Making of a German Salafiyya: The Emergence, Development and Missionary Work of Salafi Movements in Germany. Aarhus: Centre for Studies in Islamism and Radicalisation, Aarhus University.

WikTorowicz, Quintan. 2001. "The New Global Threat: Transnational Salafis and Jihad". Middle East Policy, 8.4: 18-38.

- . 2006. "Anatomy of the Salafi Movement". Studies in Conflict and Terrorism, 29.3: 207-239.

Uriya Shavit, University of Tel Aviv / Israel

> oriyasha@post.tau.ac.il 